\title{
Methodological Approaches to Assessment of the Innovation Efficiency Level at Engineering Enterprises
}

\author{
Alla Cherep* \\ Dean of the Faculty of Economics \\ Zaporizhzhia National University \\ Zaporizhzhia, Ukraine \\ cherep.av.znu@gmail.com \\ http://orcid.org/0000-0001-5253-7481 \\ Olha Hryhoriv \\ Department Department of Finance \\ Vasyl Stefanyk Precarpathian National \\ University \\ Ivano-Frankivsk, Ukraine \\ lana.gr@ukr.net
}

\author{
Olexandr Cherep \\ Department of Personnel Management \\ and Marketing \\ Zaporizhzhia National University \\ Zaporizhzhia, Ukraine \\ http://orcid.org/0000-0002-3098-0105 \\ Oksana Vasylyk \\ Department of entrepreneurship and \\ marketing \\ Ivano-Frankivsk Natonal Technical \\ University of Oil and Gas \\ Ivano-Frankivsk, Ukraine \\ vasylykoksana77@gmail.com
}

\author{
Brych Vasyl \\ Department of International Tourism \\ and Hospitality Business \\ Ternopil National Economic University \\ Ternopil, Ukraine \\ http://orcid.org/0000-0002-4277-5213
}

\begin{abstract}
The analysis of innovation in all fields of activities as well as in financial and economic areas at engineering enterprises was conducted. The innovation efficiency levels of engineering enterprises were estimated. The analysis of' availability ofinnovations was made, and the rate of their use at engineering enterprises was assessed. The methodological approach to assessment of the general level of innovation development and selection of the strategy forthe economic mechanism of innovationactivity at engineering enterprises was suggested. The methodological approach to assessment of the general level of engineering enterprises' innovation development was testedfor the purpose of applying active production, technological, marketing, innovation and investment strategy in their activities.
\end{abstract}

Keywords-strategy, innovation development, indices, efficiency, unprofitability, assessment, economic mechanism

\section{Problem Statement}

It is expedient for engineering enterprises to shape and implement a strategy of the innovationeconomic mechanism development (IEMD), which will allow determining the main areas of innovation development as well asa list of tasks and the ways of their implementation, activating the process of innovation, contributing to overcoming the state of unprofitability by enterprises, improving their performance. The use of the system of strategy formation for IEMD is a premise for implementation of the selected strategy. The given system enables shaping the main types of economic mechanism (EM) strategies, forecasting the expected effects from application of a certain strategy type, selecting a more effective strategy in the future, which will meet the capabilities of the enterprise. Despite the fact that selection of the strategy for IEMD for each enterprise is individual, since it will contribute to achievement of the expected effects in the future, it is efficient to analyse the efficiency of each strategy type and select the strategy, which takes into account all the features of business entity functioning within a specified period of time. Therefore, there is a need to develop and implement a methodological approach, whichallows analysing the main aspects of the enterprise's innovation development, selecting the optimum strategy in accordance with thedevelopment level identified and taking measures to establish activities.

\section{ANALYSIS OF RECENT RESEARCH AND PUBLICATIONS}

Currently, the issues of development, formation and implementation of innovation strategies, their efficiency assessment have been studied by a whole number of scholars, namely: Andrushkiv B. M. [1; 2; 3], Baltiukevych V. V. [4], Bartashevska Yu. M. [5], Berezniak N. V. [14], Vasylieva S. I. [23], Holda N. M. [18], Kvasha T. K. [14], Kyrych N. B. [2], Kramar I. Yu. [1], Lykun N. V. [22], Maliuta L. Ya. [3], Melnyk L. M. [2; 3], Nikolaienko A. I. [6], Onyshko S. V. [7], Orlova V. M. [8], Osovska H. V. [9], Pohaidak O. B. [1; 2], Osmirko I. V. [10], Pavlenko I. A. [11; 12], Pietukhova O. M. [13], Pysarenko T. V. [14], Plaksiienko V. Ya. [15], Polinkevych O. M. [16], Polinskyi O. M. [17], Polishchuk N. V. [18; 19], Polozova T. V. [20], Poliakova Yu. V. [21], Prudka O. V. [14], Rymar M. V. [22], Silakova H. V. [13], Spivak S. M. [2], Cherep A. V. [23], Cherep O. H. [24], Chernetska O. V. [15], Sherstiuk R. P. [2], Feshchenko A. O. [9].

However, there are the issues, which have not been covered, namely: the process of shaping the strategy of IEMDat engineering enterprises, especially implementation of the selected strategies, the mechanism of selecting a strategy in accordance with the achieved level of innovation development, the existing capabilities of the enterprise, assessment of the selected strategy efficiency and feasibility of its implementation, a set of key indices covering all aspects of innovation development, the issues of consideration of enterprises' functioning specific features when choosing a strategy. 


\section{THE AIM OF THE PAPER}

The aim of the article is to develop and test a methodological approach to assessing the general level of innovation development and selection of strategies at engineering enterprises.

\section{Discussion OF RESUlts}

First, we analysed the innovation activity in all fields as well as in financial and economic areas at the PJSC "MGT PLANT". According to the results obtained, we analysed the main components of the suggested methodological approach, i.e. assessment of innovation activity, the level of innovation efficiency, availability of innovations and the rate of their use at the enterprise for 2012-2016 [24, pp. 129-134]. The analysis of the enterprise'sinnovation level indices proved that in 2016, the majority of the indices calculated tended to decrease (Table 1).

TABLE I. INNOVATION LEVEL ASSESSMENT AT THE PJSC “MGT PLANT" FOR 2012-2016

\begin{tabular}{|l|c|c|c|c|c|}
\hline \multicolumn{1}{|c|}{ Index name } & $\mathbf{2 0 1 2}$ & $\mathbf{2 0 1 3}$ & $\mathbf{2 0 1 4}$ & $\mathbf{2 0 1 5}$ & $\mathbf{2 0 1 6}$ \\
\hline $\begin{array}{l}\text { Profitability of investment } \\
\text { in innovation }\end{array}$ & 1,14 & 5,53 & $-0,36$ & $-11,20$ & $-10,75$ \\
\hline Self-financing ratio & 4,48 & 5,00 & 5,09 & 4,55 & 4,37 \\
\hline $\begin{array}{l}\text { Information exchange } \\
\text { level in innovation activity }\end{array}$ & 0,08 & 0,12 & 0,15 & 0,09 & 0,07 \\
\hline $\begin{array}{l}\text { Index of information } \\
\text { availability and scientific } \\
\text { information dissemination }\end{array}$ & 0,12 & 0,11 & 0,13 & 0,08 & 0,06 \\
\hline $\begin{array}{l}\text { Index of the information } \\
\text { availability level in the } \\
\text { company }\end{array}$ & 0,22 & 0,18 & 0,37 & 0,22 & 0,2 \\
\hline $\begin{array}{l}\text { Efficiency of the } \\
\text { company's capital } \\
\text { investment in innovation }\end{array}$ & 0,06 & 0,01 & 0,00 & $-0,15$ & $-0,05$ \\
\hline Investment rate & 8,35 & 7,33 & 6,37 & 6,56 & 7,32 \\
\hline $\begin{array}{l}\text { Return on investment in } \\
\text { the company }\end{array}$ & 0,01 & 0,00 & 0,00 & $-0,03$ & $-0,01$ \\
\hline $\begin{array}{l}\text { Level of innovation } \\
\text { activity of the enterprise } \\
\text { (Iliae) }\end{array}$ & 1,34 & 1,51 & 1,21 & 0,12 & 0,11 \\
\hline
\end{tabular}

Compared to 2015, the following indices had negative values in 2016: return on investment in innovation, which accounted for $(-10.75)$ due to unprofitability of innovation activity, with the damage being UAH 136 in 2016; efficiency of the company's capital investment in innovation made up (-0.05), which was caused by a decrease in the amount of equity allocated to IA from UAH 3003 in 2015 down to UAH 2850 in 2016 (5\% reduction); return on investment in the company accounted for $(-0.01)$ due to a decrease in the share of own investment resources by $4 \%$ compared to 2015 (Table 2). We should emphasize that in 2016, compared to 2015, the share of own financial resources decreased, the level of availability of information and its use deteriorated, as evidenced by the $4 \%$ decrease in the self-financing ratio compared to 2015, 25\% lower availability of information and dissemination of scientific information compared to 2015.

The level of innovation efficiency at the PJSC "MGT PLANT" showed negative dynamics as well, having decreased in 2014-2016 (Table 2).
Compared to 2015, the ratio of highly qualified and skilled workers involved in science tended to reduce, having decreased by $5 \%$ due to a cut in the number of skilled workers by 2 persons and the total number of employees by 8 persons.

TABLE II. ASSESSMENT OF THE INNOVATION EFFICIENCY AT THE PJSC "MGT PLANT" FOR 2012-2016

\begin{tabular}{|l|l|l|l|l|l|}
\hline \multicolumn{1}{|c|}{ Index name } & $\mathbf{2 0 1 2}$ & $\mathbf{2 0 1 3}$ & $\mathbf{2 0 1 4}$ & $\mathbf{2 0 1 5}$ & $\mathbf{2 0 1 6}$ \\
\hline $\begin{array}{l}\text { Volume of innovation } \\
\text { productsmanufactured }\end{array}$ & 0,12 & 0,45 & 0,17 & 0,08 & 0,21 \\
\hline $\begin{array}{l}\text { Labour productivity of } \\
\text { personnel involved in ID }\end{array}$ & 5,71 & 15,81 & 9,08 & 2,12 & 3,92 \\
\hline $\begin{array}{l}\text { Increment in labour } \\
\text { productivity }\end{array}$ & 2,90 & 1,05 & 1,74 & 5,51 & 2,62 \\
\hline Profitability of operations & 0,02 & 0,01 & 0,00 & $-0,11$ & $-0,04$ \\
\hline $\begin{array}{l}\text { Profitability of innovation } \\
\text { products }\end{array}$ & 0,07 & 0,06 & 0,04 & 0,04 & 0,11 \\
\hline $\begin{array}{l}\text { Profitability of innovation } \\
\text { activity }\end{array}$ & 0,00 & 0,00 & 0,00 & $-0,02$ & $-0,01$ \\
\hline $\begin{array}{l}\text { Share of profits from } \\
\text { innovation }\end{array}$ & 0,20 & 0,00 & 0,16 & 0,25 & 0,19 \\
\hline $\begin{array}{l}\text { Product innovation ratio } \\
\text { Cost savings from } \\
\text { introduction of modern } \\
\text { equipment }\end{array}$ & 0,15 & 0,13 & $-3,35$ & $-0,20$ & $-0,32$ \\
\hline $\begin{array}{l}\text { Ratio of highly qualified and } \\
\text { skilled workers involved in } \\
\text { science }\end{array}$ & 0,16 & 0,16 & 0,16 & 0,185 & 0,175 \\
\hline $\begin{array}{l}\text { Indicator of Marketing } \\
\text { Department performance } \\
\text { efficiency }\end{array}$ & 0,11 & 0,67 & 0,32 & 0,17 & 0,31 \\
\hline $\begin{array}{l}\text { Level of the enterprise's } \\
\text { innovation efficiency (Ileie) }\end{array}$ & 0,93 & 1,32 & 0,91 & 0,86 & 0,82 \\
\hline
\end{tabular}

The reduction in the share of profits from innovation proves unprofitability of the enterprise in 2016 compared to 2015. The index decreased by $24 \%$, as the total amount of damage incurred in 2016 amounted to UAH 720 (Table 2). In 2016, the index of increment in labour productivity showed a disappointing trend as well. Compared to 2015, it decreased by $52 \%$ due to a cut in the number of personnel involved in the IA by 2 persons. The negative values of the profitability of operations index, which made up (-0.04), and the profitability of innovation activity index, which accounted for $(-0.01)$, prove deterioration of the results of production activities in 2016, which is explained by unprofitability of pre-tax profits, with the loss being 771 UAH, and unprofitability of pre-tax profits from IA, which amounted to UAH 123. At the same time, in 2016, the volume of innovation products increased by 1.6 times, compared to 2015; profitability of innovation products was 2 times as high as in 2015; product innovation ratio was 1.5 times as high compared to 2015.The growth of the above indices shows an increase in innovation products manufacture, growth of revenues and reduction of costs in 2016.

The last component under analysis is theinnovations availability and rate of their use at the enterprise, which saw a decrease in 2016 as well (Table 3 ).

The evidence of a low level of equipment availability at the enterprise anda lack of modern methods for product promotion is the reduction inavailability of computing technology for innovation development by $23 \%$, in 
thetechnology innovation index - by $19 \%$; in the ratio of own and attracted innovation technologies - by $50 \%$, in the index of equipment availability - by $57 \%$, in the indicator of innovation in marketing - by $66 \%$ in 2016 , compared to 2015. The evidence of a low level of equipment availability at the enterprise anda lack of modern methods for product promotion is the reduction inavailability of computing technology for innovation development by $23 \%$, in thetechnology innovation index - by $19 \%$; in the ratio of own and attracted innovation technologies - by $50 \%$, in the index of equipment availability - by $57 \%$, in the indicator of innovation in marketing - by $66 \%$ in 2016 , compared to 2015.

TABLE III. ASSESSMENT OF THE INNOVATIONS AVAILABILITY LEVEL AND RATE OF THEIR USE AT THE PJSC “MGT PLANT” FOR 2012-2016

\begin{tabular}{|c|c|c|c|c|c|}
\hline Index name & 2012 & 2013 & 2014 & 2015 & 2016 \\
\hline $\begin{array}{l}\text { Coefficient of technology } \\
\text { progressiveness }\end{array}$ & 0,01 & 0,06 & 0,08 & 0,1 & 0,13 \\
\hline $\begin{array}{l}\text { Coefficient of science } \\
\text { intensive production }\end{array}$ & 0,156 & 0,17 & 0,14 & 0,178 & 0,19 \\
\hline $\begin{array}{l}\text { Capacity utilization factor } \\
\text { in IA }\end{array}$ & 0,50 & 1,00 & 0,59 & 0,47 & 0,55 \\
\hline $\begin{array}{l}\text { Availability of computing } \\
\text { technology for innovation } \\
\text { development }\end{array}$ & 0,17 & 0,19 & 0,15 & 0,13 & 0,1 \\
\hline $\begin{array}{l}\text { Technology innovation } \\
\text { index }\end{array}$ & 0,16 & 0,33 & 0,25 & 0,21 & 0,17 \\
\hline $\begin{array}{l}\text { The ratio of own and } \\
\text { attracted } \\
\text { technologies }\end{array}$ & 0,09 & 0,11 & 0,18 & 0,12 & 0,06 \\
\hline $\begin{array}{l}\text { Index of equipment } \\
\text { availability }\end{array}$ & 0,31 & 0,35 & 0,27 & 0,28 & 0,12 \\
\hline $\begin{array}{l}\text { Investment rate in the } \\
\text { production process }\end{array}$ & 0,003 & 0,008 & 0,006 & 0,005 & 0,006 \\
\hline $\begin{array}{l}\text { Indicator of innovation in } \\
\text { marketing }\end{array}$ & 0,19 & 0,07 & 0,004 & 0,003 & 0,001 \\
\hline Smooth production flow & 0,28 & 0,57 & 0,43 & 0,28 & 0,29 \\
\hline $\begin{array}{l}\text { Level of innovations } \\
\text { availability at the } \\
\text { enterprise and rate of their } \\
\text { use( }\left(^{\text {Iliaeru}}\right)\end{array}$ & 0,43 & 0,53 & 0,46 & 0,42 & 0,40 \\
\hline
\end{tabular}

Note: developed by the author

Simultaneously, there was a trend towards improvementin 2016, compared to 2015, in the coefficient of technology progressiveness, which increased by $30 \%$, in the coefficient of scienceintensive production, which rose by $7 \%$, in the capacity utilization rate in IA, which grew by $16 \%$ respectively. All these indices indicatea gradual establishment of production activities.

In 2016, according to the results tested at the PJSC "MGT PLANT", the total level of innovation development was very low (Table 4, Figure 1).

In particular, in 2016, the integrated index of the innovation level decreased by $4 \%$, compared to 2015, which indicates an unfavourable investment environment of the enterprise, a lack of investment resources and reduction in their amount allocated to the IA development, a low level of information availability and dissemination. The given data show that the company was at a pre-crisis level of innovation development; there fore the use of active production, technological, marketing, innovation, investment strategy in its activities is a premise for overcoming this situation.
As far as the integrated value of the innovation efficiency level is concerned (Table 4, Figure 1), there was a $5 \%$ decrease in 2016, compared to 2015, due to the enterprise's unprofitable activities, low investment opportunities, a lack of support from the government and local authorities, minor expenditure of funds onIA, a low level of demand for manufactured products. Therefore, the total level of innovation wasaverage, and introduction of an active innovation and investment strategy is a premise for improving the enterprise's performance.

The integrated index of innovations availability and rate of their use decreased from 0.42 in 2015 to 0.40 in 2016 (a $5 \%$ reduction), that is, availability of modernequipment and its innovationwere at a low level, the Marketing Department did not introduce new ways of disseminating information about the products manufactured, most fixed assets weredepreciated and therefore it is expedient to introduce innovation equipment (Table 4, Figure. 1).

TABLE IV. ASSESSMENT OF THE TOTAL LEVEL OF INNOVATION DEVELOPMENT AND STRATEGY SELECTION OF THE PJSC "MGT PLANT" FOR 2012-2016

\begin{tabular}{|c|c|c|c|c|c|c|}
\hline 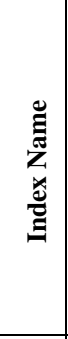 & 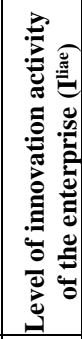 & 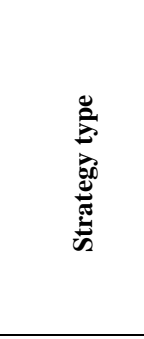 & 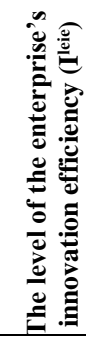 & 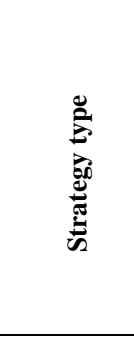 & 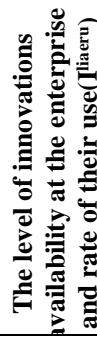 & 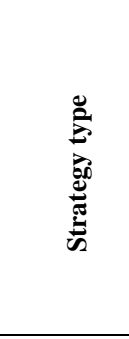 \\
\hline 2012 & 1,34 & $\begin{array}{c}\text { Passive } \\
\text { innovation }\end{array}$ & 0,93 & $\begin{array}{c}\text { Active } \\
\text { innovation }\end{array}$ & 0,43 & $\begin{array}{c}\text { Active } \\
\text { marketing, } \\
\text { innovation } \\
\text { investment }\end{array}$ \\
\hline 2013 & 1,51 & $\begin{array}{c}\text { Passive } \\
\text { innovation }\end{array}$ & 1,32 & $\begin{array}{c}\text { Passive } \\
\text { innovation }\end{array}$ & 0,53 & $\begin{array}{c}\text { Active } \\
\text { marketing, } \\
\text { innovation } \\
\text { investment }\end{array}$ \\
\hline 2014 & 1,21 & $\begin{array}{c}\text { Passive } \\
\text { innovation }\end{array}$ & 0,91 & $\begin{array}{c}\text { Active } \\
\text { innovation }\end{array}$ & 0,46 & $\begin{array}{c}\text { Active } \\
\text { marketing, } \\
\text { innovation } \\
\text { investment }\end{array}$ \\
\hline 2015 & 0,12 & $\begin{array}{c}\text { Active } \\
\text { production, } \\
\text { technology, } \\
\text { marketing, } \\
\text { innovation, } \\
\text { investment }\end{array}$ & 0,86 & $\begin{array}{c}\text { Active } \\
\text { innovation } \\
\text { investment }\end{array}$ & 0,42 & $\begin{array}{c}\text { Active } \\
\text { marketing, } \\
\text { innovation } \\
\text { investment }\end{array}$ \\
\hline 2016 & 0,11 & $\begin{array}{c}\text { Active } \\
\text { production, } \\
\text { technology, } \\
\text { marketing, } \\
\text { innovation, } \\
\text { investment }\end{array}$ & 0,82 & $\begin{array}{c}\text { Active } \\
\text { innovation } \\
\text { investment }\end{array}$ & 0,40 & $\begin{array}{c}\text { Active } \\
\text { marketing, } \\
\text { innovation } \\
\text { investmen } \\
\mathrm{t}\end{array}$ \\
\hline
\end{tabular}

In 2016, the company'slevel of innovation development was average, which requires the use of an active marketing, innovation, investment strategy. At the same time, the enterprise has all opportunities for adjustment of its production and economic, innovation development in the subsequent periods on condition of introduction of the suggested IEM strategies. 


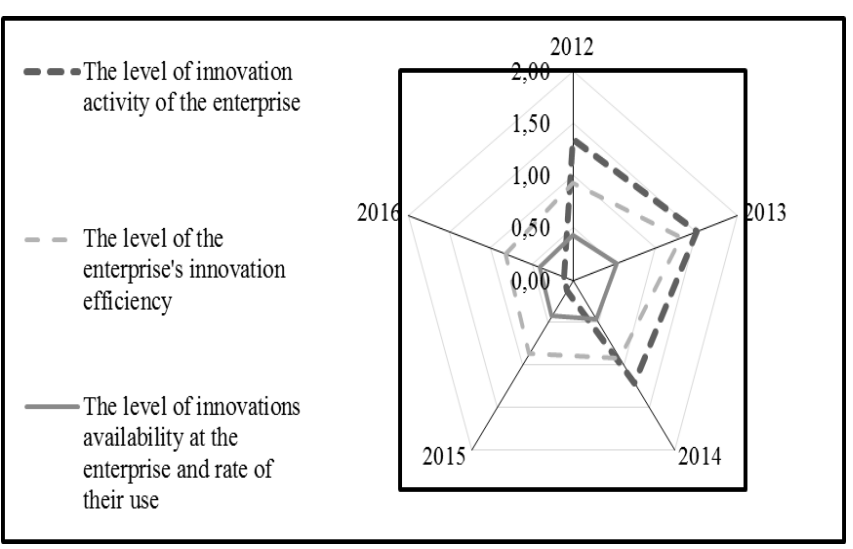

Fig. 1. The dynamics of the total level of the PJSC "MGT PLANT" innovation development for 2012-2016

Note: developed by the author

Let us proceed to the analysis of the components of the suggested methodological approach for the PJSC "Zaporizhzhia Electric Locomotive Repair Plant" in 20122016. First of all, the level of the enterprise's innovation activity was analysed, which tended to decrease in 2016 (Table 5). Most of the indicesdecreased in 2016,compared to 2015: the self-financing ratio decreased by $14 \%$ due to a reduction in the amount of own financial investments by UAH 2717, with the total investment amounting to UAH 5 thousand; the information exchange level in innovation activity decreased by $5 \%$; the index of information availability and dissemination of scientific information went down by $35 \%$ compared to 2015 ; the index of the information availability level in the company decreased by $30 \%$, compared to 2015 ; the investment ratereduced by $4 \%$. The reduction in the given indices showsunavailability of information at the enterprise, non-execution of the technology market research, a lack of attracted investment resources and own financial resources. During 2016, there was a decrease in the rate of efficiency of the company's capital investment in innovation by $70 \%$ compared to 2015 , which was caused bythe losses from the IA in the amount of UAH 1277 in 2016; by the decrease in the amount of own resources allocated to IA byUAH 1332, which indicates a lack of the enterprise's own resources.

TABLE V. INNOVATION LEVEL ASSESSMENT AT THE PJSC "MGT PLANT" FOR 2012-2016

\begin{tabular}{|l|l|l|l|l|l|}
\hline \multicolumn{1}{|c|}{ Index name } & $\mathbf{2 0 1 2}$ & $\mathbf{2 0 1 3}$ & $\mathbf{2 0 1 4}$ & $\mathbf{2 0 1 5}$ & $\mathbf{2 0 1 6}$ \\
\hline $\begin{array}{l}\text { Profitability of investment in } \\
\text { innovation }\end{array}$ & 0,13 & 5,48 & $-0,50$ & $-0,50$ & $-0,34$ \\
\hline Self-financing ratio & 0,12 & 0,17 & 0,21 & 0,39 & 0,33 \\
\hline $\begin{array}{l}\text { Information exchange level in } \\
\text { innovation activity }\end{array}$ & 0,66 & 0,57 & 0,59 & 0,61 & 0,58 \\
\hline $\begin{array}{l}\text { Index of information availability } \\
\text { and scientific information } \\
\text { dissemination }\end{array}$ & 0,55 & 0,4 & 0,57 & 0,71 & 0,46 \\
\hline $\begin{array}{l}\text { Index of the information } \\
\text { availability level in the company }\end{array}$ & 0,72 & 0,63 & 0,68 & 0,82 & 0,57 \\
\hline $\begin{array}{l}\text { Efficiency of the company's } \\
\text { capital investment in innovation }\end{array}$ & 0,01 & 0,16 & $-0,04$ & $-0,13$ & $-0,04$ \\
\hline Investment rate in the & 0,01 & 0,13 & $-0,05$ & $-0,23$ & $-0,08$ \\
\hline $\begin{array}{l}\text { Return on investment in } \\
\text { company of the }\end{array}$ & 0,67 & 1,07 & 0,60 & 0,54 & 0,51 \\
\hline $\begin{array}{l}\text { Level of innovation activity of } \\
\text { enterprise (E } E^{\text {liae }} \text { ) }\end{array}$ & \multicolumn{5}{|c|}{ Note: developed by the authors } \\
\hline
\end{tabular}

As far as the level of innovationefficiency is concerned, in 2016, the PJSC "Zaporizhzhia Electric Locomotive Repair Plant" saw a rapid decrease in this index due to the reduction in the following indicators: the profitability of operations had a negative value and amounted to -0.03 due to thepre-tax negative financial result, which amounted to UAH - 10367 in 2016; the profitability of innovation activity reached a negative value and amounted to -0.004 , as the pretax financial result of the IA was negative - -1658 UAH; the share of profits from innovation activities reduced by $24 \%$ compared to 2015 due to the IA unprofitability in 2016 , which made upUAH 1277; the cost savings from the introduction of modern equipment was negative and accounted for -0.57 (Table 6).

TABLE VI. ASSESSMENT OF THE LEVEL OF INNOVATION EFFICIENCY AT THE PJSC “ZAPORIZHZHIA ELECTRIC LOCOMOTIVE REPAIR PLANT” FOR 2012-2016

\begin{tabular}{|l|l|l|l|l|c|}
\hline \multicolumn{1}{|c|}{ Index name } & $\mathbf{2 0 1 2}$ & $\mathbf{2 0 1 3}$ & $\mathbf{2 0 1 4}$ & $\mathbf{2 0 1 5}$ & $\mathbf{2 0 1 6}$ \\
\hline $\begin{array}{l}\text { Volume of innovation } \\
\text { productsmanufactured }\end{array}$ & 0,12 & 0,45 & 0,17 & 0,08 & 0,21 \\
\hline $\begin{array}{l}\text { Labour productivity of } \\
\text { personnel involved in ID }\end{array}$ & 0,04 & 0,02 & 0,02 & 0,04 & 0,29 \\
\hline $\begin{array}{l}\text { Increment in labour } \\
\text { productivity }\end{array}$ & 11,39 & 26,02 & 22,80 & 9,49 & 1,31 \\
\hline $\begin{array}{l}\text { Profitability of operations } \\
\text { Profitability of innovation } \\
\text { products }\end{array}$ & 0,01 & 0,16 & $-0,03$ & $-0,06$ & $-0,03$ \\
\hline $\begin{array}{l}\text { Profitability of innovation } \\
\text { activity }\end{array}$ & 0,00 & 0,03 & $-0,01$ & $-0,01$ & 0,0041 \\
\hline $\begin{array}{l}\text { Share of profits from } \\
\text { innovation }\end{array}$ & 0,20 & 0,00 & 0,16 & 0,25 & 0,19 \\
\hline $\begin{array}{l}\text { Product innovation ratio } \\
\text { Cost savings from } \\
\text { introduction of modern } \\
\text { equipment }\end{array}$ & 17,11 & 0,86 & $-3,81$ & $-1,42$ & $-0,57$ \\
\hline $\begin{array}{l}\text { Ratio of highly qualified } \\
\text { and skilled workers } \\
\text { involved in science }\end{array}$ & 0,08 & 0,08 & 0,08 & 0,081 & 0,081 \\
\hline $\begin{array}{l}\text { Indicator of Marketing } \\
\text { Department performance } \\
\text { efficiency }\end{array}$ & 0,18 & 0,12 & 0,11 & 0,09 & 0,31 \\
\hline $\begin{array}{l}\text { Level of the enterprise's } \\
\text { innovation efficiency (Ileie) }\end{array}$ & 1,63 & 1,60 & 1,33 & 0,89 & 0,42 \\
\hline
\end{tabular}

Note: developed by the authors

It should be noted that in 2016 , compared to 2015 , the following indices increased: the volume of innovation products manufactured increased by 1.6 times, due to the growth of output by 8.2 times; labour productivity of personnel involved in IA increased by 6.18 times due to the rise in the volume of innovation products by 8.2 times; the Marketing Department performance efficiency increased as much as 2.4 times (Table 6). In 2016, the reduction of most indices was caused by unprofitability of the enterprise's innovation activity; however, the simultaneous growth of some indicestook place owing to the growth of the volume of innovation products manufactured and labour productivity.

The last index under consideration, the innovations availability level and rate of their use, decreased in 2016, like the other indices, which were analysed above (Table 7).

In 2016, compared to 2015, the evidence of a low level of equipment availability at the enterprise and a lack of modern methods for product promotion was the reduction in 
the capacity utilization factor in IA by $58 \%$, in the availability of computing technology for innovation development - by $24 \%$, in the technology innovation index - by $61 \%$; in the index of equipment availability - by $73 \%$; in the in the indicator of innovation in marketing - by $51 \%$; in the coefficient of technology progressiveness - by $20 \%$ (Table 7). We should emphasize that in 2016, the rate of investment in the production process had the constant value explained by the unchanged amount of investment resources in 2015-2016, which accounted for UAH 5 thousand.

According to the data analysed, the PJSC "Zaporizhzhia Electric Locomotive Repair Plant" saw deterioration in the total level of innovation development in 2016.

TABLE VII. ASSESSMENT OF THE INNOVATIONS AVAILABILITY LEVEL AND RATE OF THEIR USE AT THE PJSC "ZAPORIZHZHIA ELECTRIC LOCOMOTIVE REPAIR PLANT” FOR 2012-2016

\begin{tabular}{|l|c|c|c|c|c|}
\hline \multicolumn{1}{|c|}{ Index name } & $\mathbf{2 0 1 2}$ & $\mathbf{2 0 1 3}$ & $\mathbf{2 0 1 4}$ & $\mathbf{2 0 1 5}$ & $\mathbf{2 0 1 6}$ \\
\hline $\begin{array}{l}\text { Coefficient of technology } \\
\text { progressiveness }\end{array}$ & 0,12 & 0,45 & 0,36 & 0,41 & 0,33 \\
\hline $\begin{array}{l}\text { Coefficient of science } \\
\text { intensive production }\end{array}$ & 0,156 & 0,17 & 0,14 & 0,178 & 0,19 \\
\hline $\begin{array}{l}\text { Capacity utilization factor in } \\
\text { IA }\end{array}$ & 0,39 & 0,41 & 0,76 & 0,67 & 0,28 \\
\hline $\begin{array}{l}\text { Availability of computing } \\
\text { technology for innovation } \\
\text { development innovation }\end{array}$ & 0,31 & 0,15 & 0,22 & 0,25 & 0,19 \\
\hline $\begin{array}{l}\text { Technology index } \\
\text { index innovation }\end{array}$ & 0,64 & 0,68 & 0,72 & 0,43 & 0,31 \\
\hline $\begin{array}{l}\text { The ratio of own and } \\
\text { attracted in } \\
\text { technologies }\end{array}$ & 0 & 0 & 0 & 0,08 & 0,08 \\
\hline $\begin{array}{l}\text { Index of in } \\
\text { availability }\end{array}$ & 0,27 & 0,11 & 0,34 & 0,45 & 0,22 \\
\hline $\begin{array}{l}\text { Investment rate in the } \\
\text { production process }\end{array}$ & 0,14 & 0,12 & 0,08 & 0,05 & 0,27 \\
\hline $\begin{array}{l}\text { Indicator of innovation in } \\
\text { marketing }\end{array}$ & 0,45 & 0,33 & 0,38 & 0,44 & 0,12 \\
\hline $\begin{array}{l}\text { Smooth production flow } \\
\text { Level of innovions } \\
\text { and rate of their use(Iliaeru }\end{array}$ & 0,52 & 0,57 & 0,58 & 0,46 \\
\hline
\end{tabular}

Compared to 2015, the integrated indices of the innovation activity level at the enterprise decreased significantly in 2016, with the reduction share accounting for $5 \%$, which reflects a low level of innovation activity, lack of own and investment resources, low level of market research technologies, deterioration of the enterprise's image on the international market, lack of investment in innovation projects (Table 8, Figure. 2).

According to the integrated index, the enterprise was at the average level of innovation development and requires the introduction of an active marketing, innovation, investment strategy. In 2016, the integrated index of the level of the enterprise's innovation efficiency decreased by $53 \%$, compared to 2015 , that is, the level of innovation development in the company was average and the situation can be corrected by introducing an active marketing, innovation, investment strategy (Table 8, Figure 2). In addition, this situation arose due to a decrease in the efficiency of innovation, lack of funds for innovation development, inefficiency in the organization of the production process and sales system for innovation products, unprofitability of operations, lack of additional funding sources.

TABLE VIII. ASSESSMENT OF THE GENERAL LEVEL OF INNOVATION DEVELOPMENT AND STRATEGY SELECTION AT THE PJSC “ZAPORIZHZHIA ELECTRIC LOCOMOTIVE REPAIR PLANT” FOR 2012-2016

\begin{tabular}{|c|c|c|c|c|c|c|}
\hline 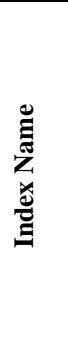 & 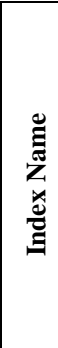 & 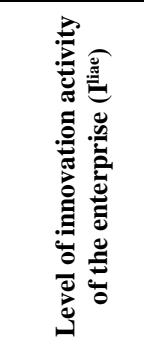 & 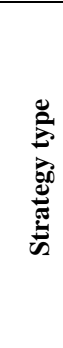 & 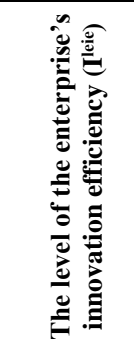 & 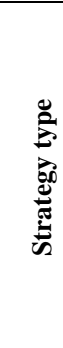 & 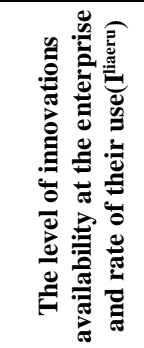 \\
\hline 2012 & 0,67 & $\begin{array}{c}\text { Active } \\
\text { innovation, } \\
\text { investment }\end{array}$ & 1,63 & $\begin{array}{c}\text { Passive } \\
\text { innovation }\end{array}$ & 0,52 & $\begin{array}{c}\text { Active } \\
\text { marketing, } \\
\text { innovation, } \\
\text { investment }\end{array}$ \\
\hline 2013 & 1,07 & $\begin{array}{c}\text { Passive } \\
\text { innovation }\end{array}$ & 1,60 & $\begin{array}{c}\text { Passive } \\
\text { innovation }\end{array}$ & 0,51 & $\begin{array}{c}\text { Active } \\
\text { marketing, } \\
\text { innovation, } \\
\text { investment }\end{array}$ \\
\hline 2014 & 0,60 & $\begin{array}{c}\text { Active } \\
\text { technology, } \\
\text { investment }\end{array}$ & 1,33 & $\begin{array}{c}\text { Passive } \\
\text { innovation }\end{array}$ & 0,57 & $\begin{array}{c}\text { Active } \\
\text { technology, } \\
\text { investment }\end{array}$ \\
\hline 2015 & 0,54 & $\begin{array}{c}\text { Active } \\
\text { marketing, } \\
\text { innovation, } \\
\text { investment }\end{array}$ & 0,89 & $\begin{array}{c}\text { Active } \\
\text { innovation }\end{array}$ & 0,58 & $\begin{array}{c}\text { Active } \\
\text { technology, } \\
\text { investment }\end{array}$ \\
\hline 2016 & 0,51 & $\begin{array}{c}\text { Active } \\
\text { marketing, } \\
\text { innovation, } \\
\text { investment }\end{array}$ & 0,42 & $\begin{array}{c}\text { Active } \\
\text { marketing, } \\
\text { innovation, } \\
\text { investment }\end{array}$ & 0,46 & $\begin{array}{c}\text { Active } \\
\text { marketing, } \\
\text { innovation, } \\
\text { investment }\end{array}$ \\
\hline
\end{tabular}

Note: developed by the author

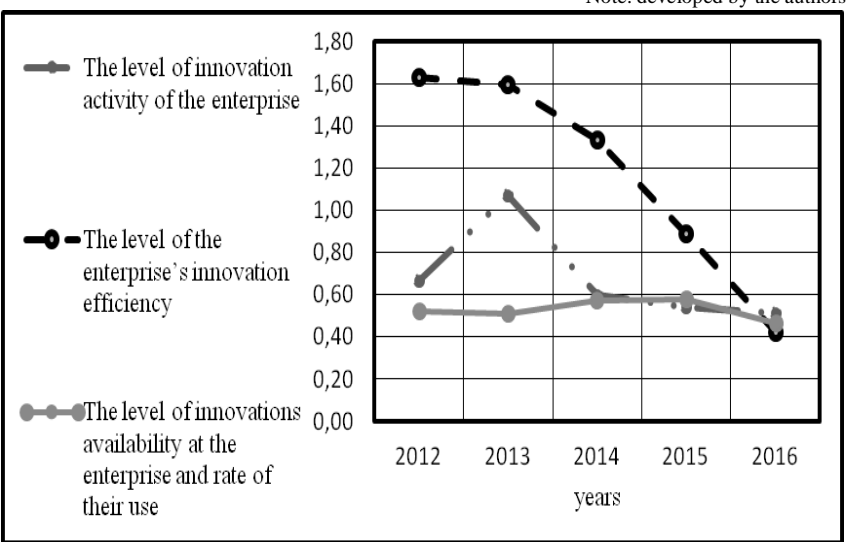

Fig. 2. The dynamics of thetotal level of innovation development atthe PJSC “Zaporizhzhia Electric Locomotive Repair Plant” for 20122016

Note: developed by the authors

In 2016, according to the integrated index of the level of innovations availability and rate of their use, the level of innovation development at the enterprise was average, which can be improved by using an active marketing, innovation, investment strategy (Table 8, Figure 2).

Compared to 2015, the reduction of the integrated index accounted for $20 \%$ in 2016, which indicates a lack of own financial resources, predominance of the share of depreciated fixed assets, inability to conduct $R \& D$ due to its unprofitability, low level of innovation development. Simultaneously, the increase in the volumes of innovation products manufactured and their sales as well as in labour 
productivity confirms a possibility to establish the activities of the PJSC "Zaporizhzhia Electric Locomotive Repair Plant" by using the suggested strategies for the economic mechanism developmentin practice, which will contribute to the IA growth.

\section{CONCLUSIONS}

The research results enable us to conclude that the methodological approach to determining the strategy efficiency ofIEMD is effective and appropriate for use in the work of engineering enterprises, since it allowed us to analyse the main components, calculate the total level of the enterprise's innovation development, correlate the results with the limits of their possible changes, select a strategy for the EMdevelopment in order to increase IA, which corresponds to the capabilities of the enterprises under analysis. Moreover, the use of this methodological approach is more reliable provided that the enterprises implement the system for formation of the IEMD strategy, which, by considering the specifics of innovation as well as production and economic activities, allowed developing several strategy types of EM development.

\section{REFERENCES}

[1] B. M. Andrushkiv, I. Yu. Kramar, O. B. Pohaidak, Innovative and complex ways of small business development, Ternopil, Ukraine: TNTU I. Puliuia, 2011. [in Ukrainian].

[2] B. M. Andrushkiv, N. B. Kyrych, O. B. Pohaidak, L. M. Melnyk, R. P. Sherstiuk, S. M. Spivak, «The strategy of consulting development in the management system of the enterprise's innovative development», Bulletin of Azov state technical University. Series: Economic Sciences, vol. 1. no. 32, pp. 141-149, 2016. [in Ukrainian].

[3] B. M. Andrushkiv, L. M. Melnyk, L. Ya. Maliuta, Applied aspects of the innovation market, Ternopil, Ukraine: TNTU I. Puliuia, 2010. [in Ukrainian].

[4] V. V. Baltyukevich, Formation of an innovation strategy of an enterprise, Odessa, Ukraine: Odessa Polytechnic University, no. 2 (36), pp. 307-311, 2011. [in Ukrainian].

[5] Yu. M. Bartashevs'ka, «Analysis of innovation development of machine-building in Ukraine», Scientific journal Series: Economic sciences, no. 5 (2), pp. 15-17, 2014. [in Ukrainian].

[6] A. I. Nikolaienko, «The mechanism of ensuring the development of the national innovation system of Ukraine», Ph. D. Thesis, Institute of Industrial Economics, National Academy of Sciences of Ukraine, Kyiv, Ukraine, 2016. [in Ukrainian].

[7] S. V. Onyshko, Financial support of innovative development, Irpin, Ukraine: National Academy of state tax service of Ukraine, 2004. [in Ukrainian].

[8] V. M. Orlova, «Innovative enterprise development strategy», Nobel Economic Herald, no. 1 (8), pp. 79-85, 2015. [in Ukrainian].
[9] H. V. Osovska, A. O. Feshchenko, «Influence of internal and external factors on the efficiency of innovation activity of the food industry», Economics and government, no. 12, pp. 83-87, 2014. [in Ukrainian].

[10] I. V. Osmirko, «System of Financial Provision of Innovation Development: Concept, Structure and Principles of Functioning», Business Inform, no. 7, pp. 47-49, 2012. [in Ukrainian]

[11] I. A. Pavlenko, Economics and organization of innovation, Kyiv, Ukraine: KNEU, $2^{\mathrm{d}}$ ed, 2006. [in Ukrainian].

[12] I. A. Pavlenko, Innovative entrepreneurship in the transformational economy of Ukraine, Kyiv, Ukraine: KNEU, 2007. [in Ukrainian].

[13] O. M. Pietukhova, H. V. Silakova, «Formation of the innovation management system of enterprises», Scientific Papers of the National University of Food Technology, no. 43, pp. 174-180, 2012. [in Ukrainian].

[14] T. V. Pysarenko, T. K. Kvasha, N. V. Berezniak, O. V. Prudka, Information support for innovation development: global and domestic experience, Kyiv, Ukraine: UkrINTEI, 2015. [in Ukrainian].

[15] V. Ya. Plaksiienko, O. V. Chernetska, «Toolkit of systems management innovation activities of enterprises», Global and national problems of economy, no. 15, pp. 403-406, 2017. [in Ukrainian].

[16] O. M. Polinkevych, «Principles of innovation in enterprise management», Economic sciences. Series: Economic and management, vol. 2, no. 7 (26), pp. 181-196, 2010. [in Ukrainian].

[17] O. M. Polinskyi, «Identification and assessment of economic risks of innovation in mechanical engineering», Regional economy, no. 3, pp. 80-88, 2011. [in Ukrainian].

[18] N. V. Polishchuk, N. M. Holda, «System of enterprises' innovation management», Bulletin of the Chernivtsi Trade and Economic Institute. Economic Sciences, no. 3, pp. 141-145, 2011. [in Ukrainian].

[19] N. V. Polishchuk, «Evaluation of the effectiveness of innovative activity of enterprises», Science and Economics, vol. 2, no. 4 (16), pp. 124-127, 2009. [in Ukrainian].

[20] T. V. Polozova, «Organizational and economic mechanism of management of innovation and investment ability of the enterprise», International Humanitarian University Herald. Economics and Management, vol. 23, no.1, pp. 126-131, 2017. [in Ukrainian].

[21] Y. V. Polyakova, «Innovative activity of industrial enterprises of Ukraine», The Bulletin of the Dnipropetrovsk University. Series: Management of Innovations, vol. 20, no. 1, pp. 74-82, 2012. [in Ukrainian].

[22] M. V. Rymar, N. V. Lykun, «Stages and principles of innovative activity of the enterprise», The Bulletin of Lviv Polytechnic National University, Series of Economics and Management, no. 725, pp. 360365, 2012. [in Ukrainian]

[23] A. V. Cherep, S. I. Vasylieva, «Development of innovation in Ukraine in modern conditions», Effective Economics, 2010. [Online]. Available: http://nbuv.gov.ua/UJRN/efek_2010_2_21. Vol. 2. Accessed on: August 4, 2019.

[24] O. H. Cherep, «Factors of the strategy formation of mechanical engineering enterprises' development in the Zaporozhye region», Humanitarian and Socio-Economic Sciences Journal, no. 4, pp. 129134., 2013. [in Ukrainian]. 